УДК 621.43

DOI: https://doi.org/10.26642/ten-2021-1(87)-9-12

Р.В. Колодницька, к.т.н., доц.

Державний університет «Житомирська політехніка»

\title{
Моделювання цетанового числа дизельних біопалив для автомобільного транспорту
}

Зниження випуску автомобілів з дизельними двигунами в Свропі, для яких характерні великі викиди як оксидів азоту, так і вуглекислого газу, призводить до того, щзо автомобілі з ичими двигунами все більше й більше продаються в Украӥні. В містах України все щее використовуються «марирутні» автобуси з дизельними двигунами, і транспортні компаніі намагаються замінити менші автобуси на більші з тим же самим дизельним двигуном. В такій ситуачії використання біодизельного палива є перспективним для України. Цетанове число палива - одна із самих важливих характеристик палива, щзо свідчить про його здатність до згоряння в ДВЗ. Точне значення ичетанового числа дизельного біопалива дуже важливе для моделювання характеристик згоряння иььго палива. Цетанові числа дизельного біопалива та його компонентів є базою для розрахунків затримки займання изи палив. Переважно дизельне біопаливо має більші значення цетанового числа, ніж дизельне паливо. В роботі виконано аналіз цетанових чисел дизельних біопалив, щчо виготовлені з використаної олії. Запропоновано формулу для підрахунку иеетанового числа таких палив з огляду на їх молекулярний склад. Одержано гарне узгодження даних моделювання цетанового числа з експерементальними даними за результатами спектрального аналізу палив. Підраховано четанові числа для компонентів (метилових ефірів жирних кислот), з яких складається дизельне біопаливо. Для того, шоб уникнути поганого розпилювання, біодизельне паливо змішується з дизельним паливом. Відновлювальне дизельне паливо має меншу густину, але більші значення цетанового числа, ніж викопне дизельне паливо. Отже, дослідження паливних характеристик сумішей дизельного біопалива з відновлювальним паливом може бути темою наступних досліджень.

Ключові слова: автомобільний транспорт; дизельне біопаливо; біодизель; иетанове число; затримка займання.

Постановка проблеми. Автомобільний транспорт - один із найбільших забруднювачів повітря в Європі, особливо у тому випадку, коли використовуються автомобілі з дизельними двигунами. Звичайно в європейських містах дуже популярні електроавтобуси i автобуси 3 паливними комірками 3 використанням водню. На жаль, поки що ці автобуси не знайшли свого широкого застосування в центральній частині України. Так в столиці України, місті Києві, ще не має жодного електроавтобуса, хоча викиди шкідливих газів в цьому місті дуже високі. Оскільки в багатьох містах України досить розвинутий тролейбусно-трамвайний транспорт, використання електроавтобусів у таких містах приведе до перевантаження електричної мережі, як вважають спеціалісти з транспортних технологій. Зниження випуску автомобілів 3 дизельними двигунами, які мають великі викиди оксидів азоту, а також викиди вуглекислого газу в Європі, призводить до того, що автомобілі з цими двигунами все більше й більше продаються в Україні. В містах України все ще використовуються «маршрутні» автобуси 3 дизельними двигунами, і транспортні компанії працюють над тим, щоб замінити менші автобуси на більші $з$ тим же самим дизельним двигуном. В такій ситуації використання біодизельного палива в суміші 3 дизельним паливом є перспективним для України. Тим більше, що Україна вирощує ріпак, який поставляється в Європейські країни для виробництва біодизеля. Далі українські водії заправляють свої автомобілі європейським дизельним паливом, у якому часто є частка біодизельного палива, яке зазвичай міститься в європейському паливі.

Аналіз останніх досліджень та публікацій. В роботі [1] була викладена концепція заміни дизельного палива альтернативним паливом. Концепцію ідеального замінника дизельного палива у ДВ3 та моделювання затримки займання дизельного біопалива було досліджено в [2]. У [3] було праналізовано властивості відновлювального дизельного палива (renewable diesel) порівняно 3 біодизельним паливом. У [4] було проаналізовано викиди від автобусів, що працюють на біодизельному паливі, використовуючи програму COPERT. Цетанові числа біодизельних палив досліджено в [5-9]. У роботі [10] було проаналізовано випаровування широкого діапазону дизельних біопалив. Випаровування біопалива різних видів може значно відрізнятися залежно від наявності компонентів, які випаровуються неоднаково. Коли паливо має у своїй структурі молекули з маленькою кількістю атомів вуглецю, воно випаровується швидше, ніж паливо 3 великою кількістю атомів вуглецю. В роботі [8] проаналізовано можливість використання як палива метилового ефіру конопляної олії, що вироблена 3 відходів виробництва, і спрогнозовано цетанове число цього біопалива. 
Метою статті $є$ дослідження цетанового числа дизельних біопалив, що вироблені з олій, які вже були у використанні.

Викладення основного матеріалу.

1. Цетанове число палива. Цетанове число $(\mathrm{CN})$ палива - одна із самих важливий характеристик, що свідчить про здатність палива до згоряння в ДВЗ. Переважно дизельне біопаливо має більші значення цетанового числа, ніж дизельне паливо. Не всі біодизельні палива мають однакові цетанові числа, оскільки цетанове число палива залежить від його молекулярної структури.

Традиційні методи визначення цетанового числа дизельних біопалив зазвичай не мають великої точності. CN дизельних біопалив може бути підраховане за його молекулярним складом [7, 8]. Цетанові числа для метилових ефірів рослинних олій (що $є$ найбільш розповсюдженими дизельними паливами) наведені в [3]. У роботі [7] було запропоновано використовувати результати спектрального аналізу для прогнозування цетанового числа палива. В роботі [8] пошук цетанового числа дизельних біопалив відбувався за такою формулою:

$$
\begin{aligned}
& C N=61,1+0,088(\mathrm{C} 14: 0)+0,133(\mathrm{C} 16: 0)+0,152(\mathrm{C} 18: 0)-0,101(\mathrm{C} 16: 1)- \\
& -0,039(\mathrm{C} 18: 1)-0,243(\mathrm{C} 18: 2)-0,395(\mathrm{C} 18: 3)
\end{aligned}
$$

Значення цетанового числа, що підраховані за формулою (1), показані як $C N$ FAM в таблиці 1. Так значення цетанового числа (CN FAM), що одержані зі складу палива, значно менші, ніж значення, одержані з аналізу спектральних даних (CN NIR) в роботі [7].

В цій роботі було запропоновано використовувати для підрахунку цетанового числа біопалив, що одержані з використаних олій, таку формулу:

$$
\begin{aligned}
& C N=62,7+0,088(\mathrm{C} 14: 0)+0,133(\mathrm{C} 16: 0)+0,152(\mathrm{C} 18: 0)-0,101(\mathrm{C} 16: 1)- \\
& -0,036(\mathrm{C} 18: 1)-0,241(\mathrm{C} 18: 2)-0,395(\mathrm{C} 18: 3)
\end{aligned}
$$

Значення цетанового числа (CN Нове), що підраховані за цією формулою, показані в останній колонці таблиці 1. Аналіз свідчить, що формула (2) дає більш точні значення цетанових чисел для палив, що розглядалися, і може бути рекомендована для моделювання затримки займання та інших параметрів згоряння біопалив. В таблиці 1 представлено молекулярний склад палив, а також значення цетанових чисел для зразків біодизельного палива, виготовленого 3 олії, яка вже була у використанні, згідно 3 даними [7].

Табличя 1

Значення иетанових чисел біопалив, щяо виготовлені з використаних олій

\begin{tabular}{|l|c|c|c|c|c|c|c|c|c|c|}
\hline \multicolumn{1}{|c|}{ Зразок } & $\begin{array}{c}\text { С14:0 } \\
(\%)\end{array}$ & $\begin{array}{c}\text { C16:0 } \\
(\%)\end{array}$ & $\begin{array}{c}\text { C16:1 } \\
(\%)\end{array}$ & $\begin{array}{c}\text { C18:0 } \\
(\%)\end{array}$ & $\begin{array}{c}\text { C18:1 } \\
(\%)\end{array}$ & $\begin{array}{c}\text { C18:2 } \\
(\%)\end{array}$ & $\begin{array}{c}\text { C18:3 } \\
(\%)\end{array}$ & $\begin{array}{c}\text { CN } \\
\text { FAM } \\
{[7]}\end{array}$ & $\begin{array}{c}\text { CN } \\
\text { NIR } \\
{[7]}\end{array}$ & $\begin{array}{c}\text { CN } \\
\text { Hoвe } \\
(2)\end{array}$ \\
\hline 32 Оливкова & 0,02 & 11,3 & 3,7 & 0,61 & 74,5 & 4,7 & 0,19 & 59,0 & 60,4 & 60,2 \\
\hline 33 Оливкова & 0,00 & 11,5 & 3,6 & 0,66 & 74,9 & 4,5 & 0,17 & 59,0 & 60,0 & 60,3 \\
\hline 34 Оливкова & 0,09 & 13,0 & 2,7 & 1,10 & 67,9 & 12,6 & 0,20 & 57,4 & 58,0 & 58,9 \\
\hline 35 Оливкова & 0,16 & 13,9 & 3,2 & 0,90 & 72,9 & 5,3 & 0,19 & 59,2 & 60,1 & 60,5 \\
\hline 36 Вичавки & 0,06 & 13,7 & 3,1 & 0,82 & 68,0 & 12,8 & 0,22 & 57,5 & 59,0 & 58,9 \\
\hline 37 Вичавки & 0,06 & 13,9 & 2,6 & 0,68 & 69,1 & 10,7 & 0,19 & 57,9 & 62,5 & 59,4 \\
\hline 38 Соняшник & 0,14 & 8,0 & 3,0 & 0,22 & 38,7 & 47,8 & 0,10 & 49,4 & 49,7 & 50,6 \\
\hline 39 Соняшник & 0,35 & 8,5 & 3,1 & 0,35 & 46,6 & 39,2 & 0,12 & 51,3 & 52,2 & 52,5 \\
\hline 40 Суміш & 0,12 & 7,6 & 3,1 & 0,34 & 31,2 & 55,4 & 0,13 & 47,8 & 48,2 & 49,0 \\
\hline 41 Оливкова & 0,04 & 13,3 & 3,5 & 0,91 & 74,9 & 5,0 & 0,21 & 59,1 & 60,4 & 60,4 \\
\hline 42 Оливкова & 0,13 & 13,8 & 3,9 & 0,97 & 74,2 & 4,7 & 0,13 & 59,4 & 62,3 & 60,6 \\
\hline 43 Оливкова & 0,10 & 7,7 & 3,8 & 0,12 & 31,5 & 55,6 & 0,10 & 47,9 & 50,8 & 48,9 \\
\hline 44 Оливкова & 0,05 & 10,6 & 3,4 & 0,61 & 62,7 & 21,6 & 0,15 & 55,2 & 56,1 & 56,5 \\
\hline 45 Соняшник & 0,08 & 7,2 & 3,1 & 0,13 & 31,4 & 55,9 & 0,09 & 47,7 & 48,5 & 48,8 \\
\hline 46 Соняшник & 0,15 & 8,3 & 3,0 & 0,31 & 34,5 & 51,3 & 0,09 & 48,8 & 49,6 & 50,0 \\
\hline 47 Суміш & 0,05 & 9,4 & 2,9 & 0,56 & 74,3 & 10,5 & 0,19 & 57,2 & 57,8 & 58,6 \\
\hline 48 Соняшник & 0,08 & 8,1 & 3,2 & 0,28 & 34,8 & 52,7 & 0,13 & 48,4 & 48,8 & 49,6 \\
\hline 49 Суміш & 0,06 & 11,6 & 3,0 & 0,68 & 58,3 & 25,0 & 0,16 & 54,6 & 54,1 & 56,0 \\
\hline 50 Оливкова & 0,17 & 13,2 & 4,3 & 1,26 & 69,2 & 9,2 & 0,15 & 58,4 & 58,7 & 59,6 \\
\hline
\end{tabular}

Дизельне біопаливо складається 3 метилових ефірів жирних кислот. Позначення компонентів, шо наведене в таблиці 1 (перша колонка), місить кількість атомів вуглецю в молекулі жирної кислоти, 3 якої виготовляється метиловий ефір, і кількість подвійних зв’язків у молекулі. Наприклад, позначення С18:3 показує 18 атомів вуглецю і 3 подвійних зв'язки.

На рисунку 1 показано порівняння цетанових чисел для біодизельних палив, виготовлених 3 різних зразків олії, що була у вжитку (табл. 1). Так значення цетанового числа, що одержані за допомогою NIR, мають більші значення, ніж ті, що підраховані за складом біопалива. 


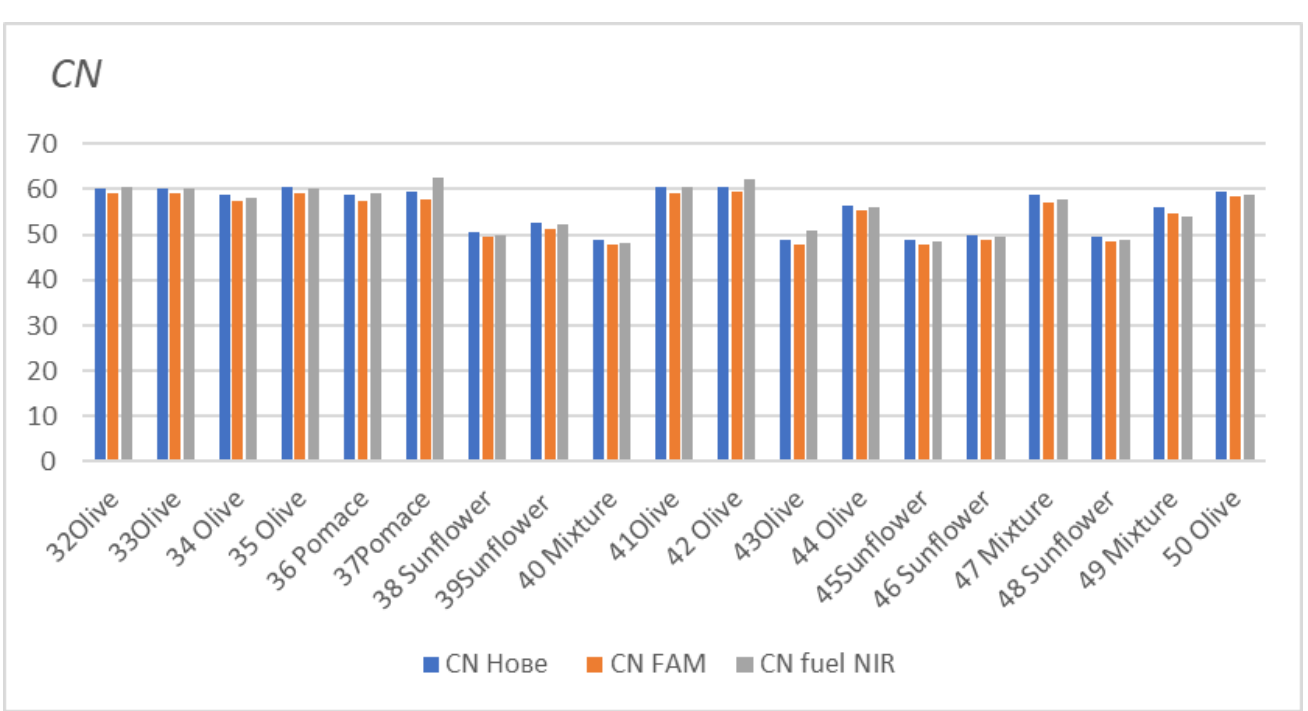

Рис. 1. Моделювання цетанового числа (CN) для біодизельних палив, щзо виготовлені з використаної олії

В таблиці 2 показані коефіцієнти 3 формул (1) і (2) та цетанові числа для складових молекул біодизельного палива, пораховані за формулами із розрахунку, що у складі палива міститься тільки одна молекула.

Таблиия 2

Значення иетанових чисел дизельного біопалива, щุо одержані різними методами

\begin{tabular}{|c|c|c|c|c|c|}
\hline Позначення & $\begin{array}{c}\text { Коефіціснти. } \\
\text { Формула (1) }\end{array}$ & $\begin{array}{c}\text { Цетанове число. } \\
\text { Формула (1) }\end{array}$ & $\begin{array}{c}\text { Нові } \\
\text { коефіцієнти. } \\
\text { Формула (2) }\end{array}$ & $\begin{array}{c}\text { Нове цетанове } \\
\text { число. } \\
\text { Формула (2) }\end{array}$ & $\begin{array}{c}\text { Експериментальні } \\
\text { цетанові числа } \\
{[6]}\end{array}$ \\
\hline$C \mathrm{~N} 0$ & 61,1 & & 62,7 & & 62,7 \\
\hline$C 12: 0$ & 0 & 61,1 & 0 & 71,5 & 73,$5 ; 66,2$ \\
\hline$C 14: 0$ & 0,088 & 69,9 & 0,088 & 76 & 74,5 \\
\hline$C 16: 0$ & 0,133 & 74,4 & 0,133 & 52,6 & $51,0[5]$ \\
\hline$C 18: 0$ & 0,152 & 76,3 & 0,153 & 56,9 \\
\hline$C 18: 1$ & $-0,101$ & 51 & $-0,101$ & 39,1 & 59,3 \\
\hline$C 18: 2$ & $-0,039$ & 57,2 & $-0,036$ & 38,6 & 45,7 \\
\hline$C 18: 3$ & $-0,243$ & 36,8 & $-0,241$ & 23,2 & \\
\hline
\end{tabular}

Як видно з таблиці 2, цетанове число, одержане за новою формулою, показує краще узгодження 3 експериментальними даними [6], ніж попередня модель. Таблиця 2 місить також експериментальні дані 3 визначення цетанового числа, що приведені в роботі [6], використовуючи традиційні експериментальні методи. Точне значення цетанового числа дизельного біопалива дуже важливе для моделювання характеристик згоряння цього палива. Цетанові числа дизельного біопалива та його компонентів $\epsilon$ базою для розрахунків затримки займання цих палив. Особливо важливо одержати достовірну інформацію про цетанові числа молекул C18:1 та С18:2, оскільки біодизельні палива, зазвичай містять найбільший відсоток цих молекул.

2. Суміші біодизельного палива 3 іншими паливами. Для того щоб уникнути поганого розпилювання, біодизельне паливо змішується з дизельним паливом. Але таке паливо не можна вважати екологічним, оскільки дизельне паливо містить у своєму складі канцерогени. Останнім часом в Свропі популярності набирає синтетичне та відновлювальне дизельне паливо. Властивості цих палив та характеристики процесів розпилювання наведені в роботі [3]. Відновлювальне диезльне паливо має меншу в'язкість, ніж біодизельне паливо, але більшу, ніж дизельне паливо. Густина відновлювального палива менша, ніж дизельного палива. Це паливо також показує менші витрату палива та викиди оксидів азоту порівняно з біодизельним паливом. Відновлювальне паливо має більші значення цетанового числа, ніж дизельне паливо. Отже, дослідження паливних характеристик сумішей дизельного біопалива 3 відновлювальним дизельним паливом може бути темою наступних досліджень.

Висновки та перспективи подальших досліджень. В роботі виконано аналіз цетанових чисел різних зразків дизельних біопалив, що виготовлені з олії, яка вже була у вжитку. Запропоновано формулу для підрахування цетанового числа таких біопалив з огляду на їх молекулярний склад. Одержано гарне узгодження даних моделювання цетанового числа біопалив 3 експерементальними даними за 
результатами спектрального аналізу. Підраховано цетанові числа для компонентів (метилових ефірів жирних кислот), з яких складається дизельне біопаливо. Дані моделювання цетанових чисел компонентів добре узгоджуються 3 експериментальними значеннями, що одержані за допомогою традиційних експериментальних методів.

\section{Список використаної літератури:}

1. Колодницька Р.В. Концепція ідеального замінника дизельного палива у ДВЗ : тези ХІІІ міжнарод. наук.практ. конф. «Сучасні технології та перспективи розвитку автомобільного транспорту», 26-28 жовт. 2020 р. / Р.В. Колодницька, О.П. Кравченко. - С. 31-33.

2. Колодницька Р.В. Моделювання затримки займання дизельного біопалива / P.В. Колодницька // Технічна інженерія. - 2020. - № 2 (86). - С. 13-17.

3. Колодницька Р.В. Відновлювальне дизельне паливо та синтетичне паливо як альтернатива для дизельного палива / Р.В. Колодницька, О.П. Кравченко // Вісник Житомирського державного технологічного університету. Серія : Технічні науки. - 2019. - № 1 (83). - С. 3-11.

4. Колодницька P.B. Використання програми COPERT для підрахунку викидів автомобільного транспорту: тези XIII міжнарод. наук.-практ. конф. «Сучасні технології та перспективи розвитку автомобільного транспорту», 26-28 жовт. 2020 р. / Р.В. Колодницька. - С. 29-30.

5. Inference of the biodiesel cetane number by multivariate techniques / D.V. Nadai, J.B. Simões, C.E.N. Gatts, P.C.M.L. Miranda // Fuel. - 2013. - № 105. - P. 325-330.

6. Compendium of Experimental Cetane Numbers : Technical Report NREL/TP-5400-67585 / J.Yanowitz, M.A. Ratcliff, R.L. McCormick et al. - National laboratory of the U.S. Department of Energy, 2017 [Electronic resource]. - Access mode : https://www.nrel.gov/docs/fy17osti/67585.pdf.

7. Cetane number prediction of waste cooking oil-derived biodiesel prior to transesterification reaction using near infrared spectroscopy / J.F. Garcia-Martín, F.J. Alés-Álvarez, M.C. López-Barrera et al. // Fuel. - 2019. - № 240. - P. 10-15.

8. Колодницька P.B. Процеси випаровування та згоряння дизельного біопалива у двигунах внутрішнього згоряння : монографія / Р.В. Колоднищька. - Житомир : ЖДТУ, 2018. - 192 с.

9. Giakoumis E.G. Comparative Assessment of Biodiesel Cetane Number Predictive Correlations Based on Fatty Acid Composition / E.G. Giakoumis, C.K. Sarakatsanis // Energies, No. 12, P. 422.

10. Modelling of biodisel fuel droplet heating and evaporation / S.S. Sazhin, M. Al Qubeissi, R.Kolodnytska et al. // Fuel. - 2014. - № 115. - P. 559-572.

\section{References:}

1. Kolodnyc'ka, R.V. and Kravchenko, O.P. (2020), «Koncepcija ideal'nogo zaminnyka dyzel'nogo palyva u DVZ», tezy XIII mizhnarod. nauk.-prakt. konf. «Suchasni tehnologii' ta perspektyvy rozvytku avtomobil'nogo transportu», 26-28 zhovt. 2020 r., pp. 31-33.

2. Kolodnyc'ka, R.V. (2020), «Modeljuvannja zatrymky zajmannja dyzel'nogo biopalyva», Tehnichna inzhenerija, No. 2 (86), pp. 13-17.

3. Kolodnyc'ka, R.V. and Kravchenko, O.P. (2019), «Vidnovljuval'ne dyzel'ne palyvo ta syntetychne palyvo jak al'ternatyva dlja dyzel'nogo palyva», Visnyk Zhytomyrs'kogo derzhavnogo tehnologichnogo universytetu, Serija Tehnichni nauky, No. 1 (83), pp. 3-11.

4. Kolodnyc'ka, R.V. (2020), «Vykorystannja programy COPERT dlja pidrahunku vykydiv avtomobil'nogo transportu», tezy XIII mizhnarod. nauk.-prakt. konf. «Suchasni tehnologii' ta perspektyvy rozvytku avtomobil'nogo transportu», 26-28 zhovt. 2020 r., pp. 29-30.

5. Nadai, D.V., Simões, J.B., Gatts, C.E.N. and Miranda, P.C.M.L. (2013), «Inference of the biodiesel cetane number by multivariate techniques», Fuel, No. 105, pp. 325-330.

6. Yanowitz, J., Ratcliff, M.A., McCormick, R.L. et al. (2017), Compendium of Experimental Cetane Numbers, Technical Report NREL/TP-5400-67585, National laboratory of the U.S. Department of Energy, [Online], available at: https://www.nrel.gov/docs/fy17osti/67585.pdf

7. García-Martín, J.F., Alés-Álvarez, F.J., López-Barrera, M.C. et al. (2019), «Cetane number prediction of waste cooking oil-derived biodiesel prior to transesterification reaction using near infrared spectroscopy», Fuel, No. 240, P. 10-15.

8. Kolodnyc'ka, R.V. (2018), Procesy vyparovuvannja ta zgorjannja dyzel'nogo biopalyva u dvygunah vnutrishn'ogo zgorjannja, monografija, ZhDTU, Zhytomyr, 192 p.

9. Giakoumis, E.G. and Sarakatsanis, C.K., «Comparative Assessment of Biodiesel Cetane Number Predictive Correlations Based on Fatty Acid Composition», Energies, No. 12, pp. 422.

10. Sazhin, S.S., Al Qubeissi, M., Kolodnytska, R. et al. (2014), «Modelling of biodisel fuel droplet heating and evaporation», Fuel, No. 115, pp. 559-572.

Колодницька Руслана Віталіївна - кандидат технічних наук, доцент Державного університету «Житомирська політехніка».

Наукові інтереси:

- альтернативні палива для автомобільного транспорту;

- автомобілі з паливними комірками;

- транспортні технології.

E-mail: ruslanakolod2017@gmail.com. 